\title{
AN INTEGRATIVE HIERARCHICAL SPATIAL FRAMEWORK FOR SPRING HABITATS
}

\author{
MARTIN REISS \\ Philipps-Universität Marburg, Fachbereich Geographie, Deutschhausstr. 10, 35032 \\ Marburg,email: reissm@geo.uni-marburg.de
}

Received: $10^{\text {th }}$ July 2013, Accepted: $15^{\text {th }}$ November 2013

\begin{abstract}
A theoretical approach of a hierarchical spatial framework concept for spring habitats is presented in this paper. The concept is based on existing classifications of running water and on empirical studies of spring ecosystems. Hierarchical spatial categorisation is applied to study spring areas of forest ecosystems in low mountain ranges of Germany. A spatial concept for springheads is designed to aid the illustration and understanding of functional, structural and process relationships on different scales. Here, multiple geographical dimensions and hydrological scales and their terms are compared in an integrated system. This integrated approach is needed if a water body is to be studied as an ecosystem rather than just a hydrological system. The goal of this hierarchical spatial framework is to establish a conceptual foundation for the study of fauna-microhabitat relationships and for the analysis of the substrate preference of the invertebrate fauna of spring ecotones. This paper presents a surface water typology for patchy forest springs with different habitat types. Most of these habitat types of the 152 investigated springs are dominated by organic substrate types as micro habitats $(74.7 \%)$ with subdominant mineral substrate types. Therefor the most dominant habitat type (HT) is "CPOM dominated, Psammopelal abounded" HT (19.7 \%), followed by the HT "Macrophytes dominated, Psammopelal abounded" (13.2\%) and the HT "CPOM dominated, Microlithal abounded" (9.9\%). More underrepresented habitat types are pure mineral substrate types $(10.5 \%)$ like the HT "Psammopelal dominated" (5.9\%). There were also less artificial habitat types $(7.2 \%)$, because the study focused on undisturbed spring habitats inside the field survey.
\end{abstract}

Key words: geographical dimension, scales, hierarchical theory, spring water typology

\section{BACKGROUND AND OBJECTIVES}

An overall aim of landscape research is to provide a scientific basis for sustainable landscape and environmental development within a social and political climate (Drdoš 1983). Man is not only part of geo-ecosystems, he is the main driver, so that anthropogenic factors are crucial in influencing the ecological state, function and process. This is central to the concept of the Anthropocene (Crutzen 2006; see also Ehlers 2008) or the Total Human Ecosystem (Naveh 2000). Water and water bodies are a part of that landscape and are interconnected in the water cycle within the landscape water regime (Bracken and Croke 2007; Wohlrab et al. 1999). Springs, which occur where groundwater reaches the 
surface, are an integrative part of this system. As a habitat, springs are ecotones, interfaces between subterranean and above-ground environments (Gibert et al. 1991). The spatial scale of springs in the European Low Mountain Ranges is generally small; for example, the vegetation around Helocrene springs has an average size of five square meters (Dierschke 1994). In the sense of geographic dimensions, springs can be classified as homogeneous units on the topological level, but Neef (1963) shows that a quantitative description can achieve a more precise statement about the ecosystem, its elements and their function. One such element in a spring ecosystem is the substrate, whose function is to provide a habitat for organisms, especially invertebrates. The spring or eucrenal itself is not a discrete entity in the topological dimension, because it is made of different substrate types that build mosaic-like structures or patches (see Kotliar and Wiens 1990 for the term patch and the concept of heterogeneity; for the patch dynamic concept see Pickett and White 1985). It is possible to subdivide the spring level into subtopic dimensions or nanoscales (Duttmann et al. 2000), such as a segment or reach system of a river (see Frisell et al. 1986), because the substrata are inhabited by invertebrates and other organisms.

A hierarchical spatial framework for springs, especially for the eucrenal, is necessary and useful for several reasons: 1) A hierarchical spatial framework has been made only for larger-scale running water, such as rivers (Frisell et al. 1986; Thomson et al. 2001; see summary in Allan and Castillo 2007), and a similar theoretical approach for springs as a different surface water ecosystem is not known (Schönborn 2003); 2) there are different terms and classifications for water systems in hydrology and landscape ecology depending on their dimensions and scale (Reiss 2011); 3) research designs and study programs only slightly consider the relationship between river networks and hydrotopes within the catchment in identifying the ecological functions of spring habitats (Czachorowski 1999); 4) at the topological dimension, the water structures of springs are patchy and heterogeneous, and a method to characterise microhabitats of different substrate types is still lacking (Cantonati et al. 2012); and 5) spatially hierarchical reference systems support the identification of the relationship between structures (hydro-morphology) and functions in surface water types (Poole 2002).

The objectives of this research are to determine an integrative hierarchical spatial framework for cold springs (springs with a water temperature related to the mean annual local air temperature) and to serve a theoretical basis for an ecological assessment of the microhabitat-fauna relationship. In this sense, "integrative" means the intention to bring hydrological and landscape ecological scales into a spatio-functional context. The focus of this concept is to differentiate the habitat of the eucrenal of a spring into several microhabitats. The purpose is to study the relevance of a substrate-based surface water typology by determining the microhabitat subtypes of the major spring types (Helocrene, Rheocrene and Limnocrene).

\section{METHODS AND STUDY AREA}

For the topic and particularly the subtopic dimensions (micro- and nanoscale), a method to detect substrate types within spring ecosystems and to sample the invertebrate fauna of each type was developed. Therefore, a new multi-habitat sampling with a 2-layer approach was realised (Reiss 2011). The principle is similar to the AQEM/STAR approach to assess the riverbed of river segments (Cheshmedjiev et al. 2011; Meier et al. 2006), but with biotope-specific basic changes in the procedure. The inorganic and organic layers are considered individually in a 2-layer approach by taking the area of the whole spring habitat 
as a reference surface (5-10 square meters). The number of sub-samples taken in each layer corresponds to the fraction of the substrate types of the reference surface that layer has, with one sample taken per 5 per cent coverage. Comparison charts were used for the estimation of the coverage of substrate types (Gehlker 1977). For each sample, a substratespecific sampling technique (e.g., sampling by net, collecting with tweezers) is performed for 2 minutes over the $10 \mathrm{~cm}$ by $10 \mathrm{~cm}$ reference area. Mapping and sampling were taken once a time for 152 springs for a first representative overview between February and September 2008 (with a focus on March and June till August). A control monitoring sampling from early spring to summer 2009 of 4 representative helocrene springs showed that there were minor changes in the variability of substrate coverage depending to the substrate type. Only CPOM varies from minimum 20 per cent coverage in summer to maximum 70 per cent coverage in early spring. A result of the substrate type assessment and the microhabitat type modelling (Reiss 2011) is shown in Table 2, which is an empiric finding of the substratum monitoring procedure of all investigated springs of the study areas. As a descriptive statistics method the relative frequency $\left(\mathrm{f}_{\mathrm{i}}\right)$ was calculated $\left(\mathrm{f}_{\mathrm{i}}=\mathrm{n}_{\mathrm{i}} /\right.$ $\mathrm{N} ; \mathrm{n}_{\mathrm{i}}$ : absolute frequency; $\mathrm{N}$ : total number of samples) to compare the habitat type occurrence of the different substrate types. Eighty per cent of all samples in Table 2 are Helocrenes.

The investigation program of spring ecosystems in forests (Table 1) was carried out in the central parts of Germany in the Federal States of Hesse (Hessen) and Thuringia (Thüringen) (Fig. 1). Six study areas were investigated: 1) Kellerwald (National Park KellerwaldEdersee; 40 springs), 2) Burgwald (30 springs), 3) Krofdorfer Forst (38 springs), 4) Vogelsberg (Forest Reserve Niddahänge; 24 springs), 5) Rhön (Biosphere Reserve, Core Zone and Forest Reserve Schafstein; 9 springs) and 6) Hainich (National Park Hainich; 11 springs). The study areas were selected to guarantee a wide spectrum of substrate types and a diversity of hydro-morphological structures. Furthermore, there is little to no known previous spring ecological research in these study areas.

Fig. 1: Location of study areas in Germany.

\section{Location of study areas (Germany)}
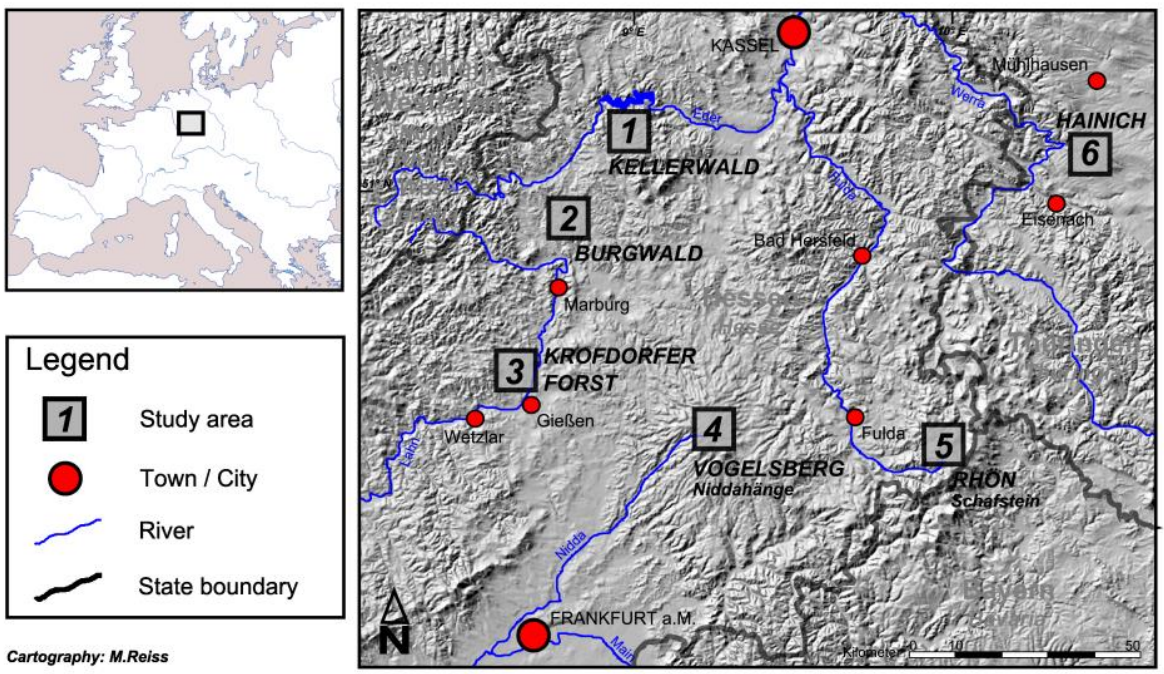


\section{A THEORETICAL SPATIAL FRAMEWORK FOR SPRING HABITATS}

The fundamental concept of the investigational approach is based on the consideration that aquatic ecosystems are "strongly influenced by landform and land use within the surrounding valley at multiple scales" (Allan 2004). This means that the water body must be integrated into the landscape or watershed inside a natural-spatial unit. The term riverscape (Allan 2004) may also encompass the term springscape. The integrative and functional unit in hydrology is the catchment (Aspinall and Pearson 2000), whereby an attempt is made to integrate a variety of environmental processes and human impacts on landscapes by bringing methodological concepts of landscape ecology and hydrology into a common context: "Again, composition and configuration of structural elements determine the catchment pattern. This pattern is related to terrain, soil, biota and their respective interactions $\ldots$ that control spatially dependent catchment processes and functions" (Schröder 2006:969). Figure 2 shows the classification of springs in a watershed context.

Fig. 2: Classification of springs in a watershed context within a hierarchical spatial framework, following the method of Volk and Steinhardt (1999).

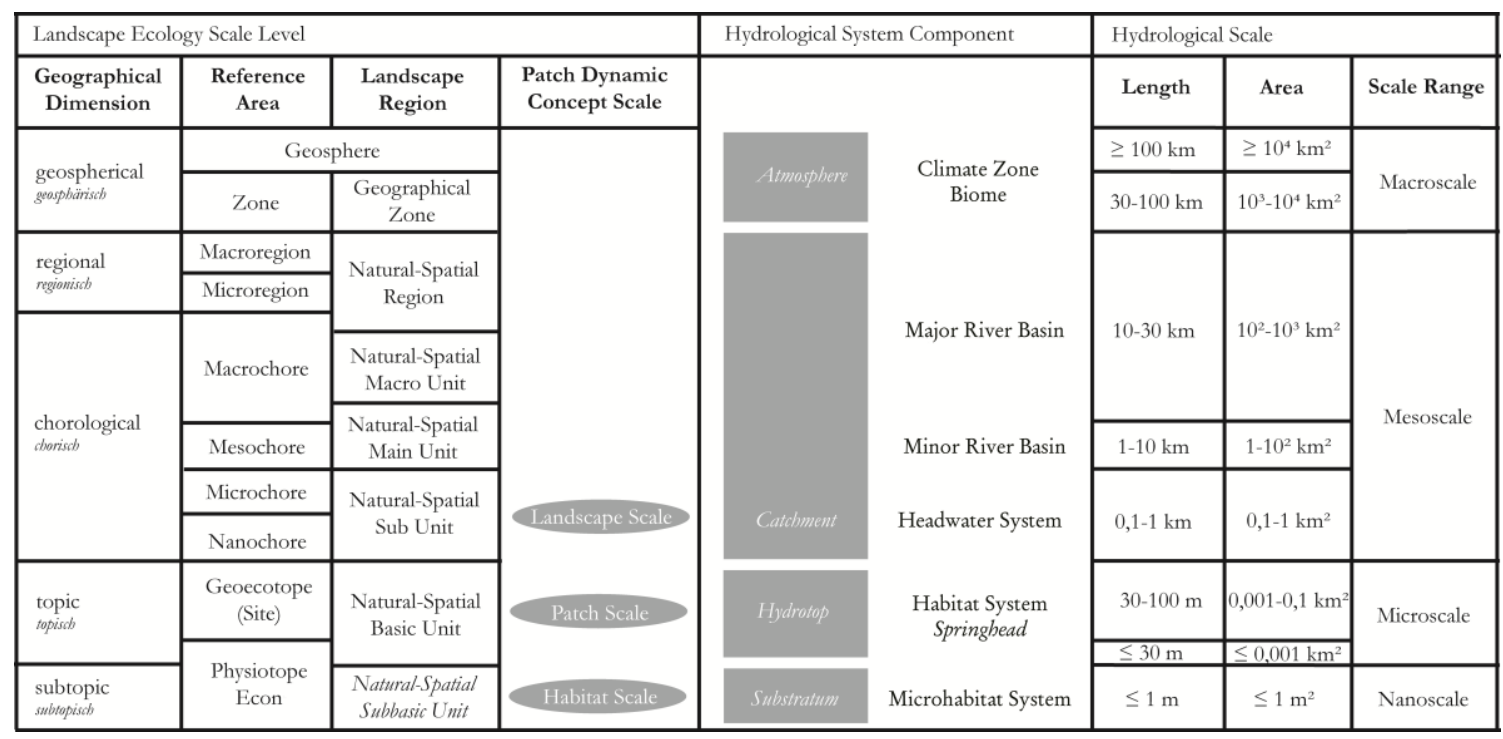

The substratum within the substrate type is arranged at the nanoscale level, which corresponds to the habitat scale of the patch dynamics concept or the microhabitat system (Gibert 1991; Gibert et al. 1990). A small-scale analysis of the structural characteristics of microhabitats and their faunistic colonisation could be performed at the level of the local, within-plot scale for ecological field studies, following the method of Morrison et al. (2006). The substratum within the nanoscale / habitat scale is not congruent to the Physiotop (Schmithüsen 1949), but here it is associated with the subtopic dimension to integrate the hydrological scale level (Fig. 2). However, this association implies a smooth transition between the subtopic and topic dimensions. The springhead (eucrenal) is the ecotope at the topic dimension. It corresponds to the patch scale of the patch dynamics concept or the habitat system. The range of a springhead is comparable with the segment or reach system of running waters. The substrate types of the substratum form a mosaic (see 
also Fig. 3) within a hydrotope, which is the smallest hydrological system (hydrological response unit or HRU; Gurtz et al. 1999). In the Interreg Project KATER II, the hydrotope concept was used to define GIS-based protection areas for springs as drinking water resources in karst forests (Magagna et al. 2006). The spring area (springhead and spring brook, or eucrenal and hypocrenal) marked the transition to the chorological dimension (nanochore) but is also a part of the mesoscale within the stream system (see the spatial concept of a spring area in Reiss and Opp 2004). Multiple spring areas of a small headwater catchment reach the level of the microchore. Several spring catchments are taken together in a higher-level system of a river catchment. Spring and river catchments are part of the landscape scale of the patch dynamics concept. Finally, such stream systems can be a part of major, continent-scale river basins (micro- to macroregional dimensions).

An analysis of the components and functions of a spring ecosystem from each dimension or scale requires a specific spatial-based research method (Fig. 3 and Table 1).

\section{Fig. 3: The springscape: A hierarchical spatial system of springs.}

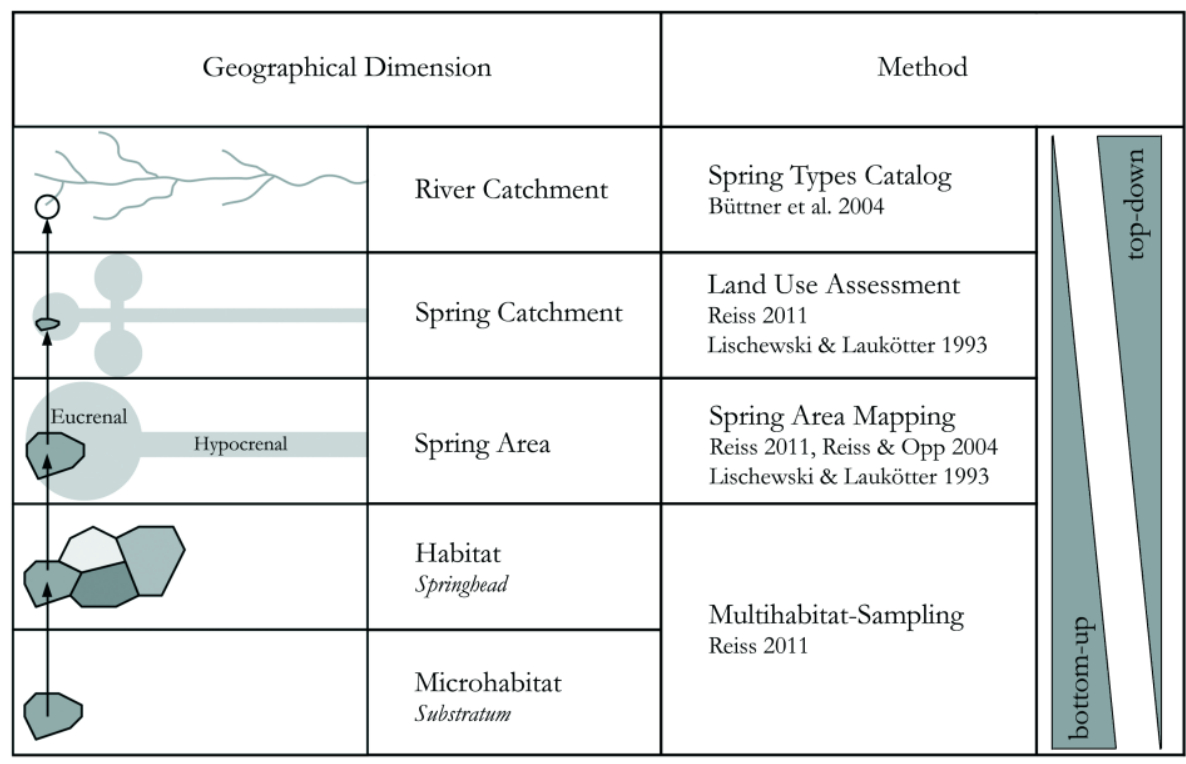

As a result, functional relations through down- and upscaling can be discovered by performing an integrated system analysis. For example, considering the mesoscale characteristics of catchments is useful for nano- and microscale studies of springs. Documenting rock-related properties in a watershed allow subdivision into the categories of carbonate and siliceous springs. Certain species prefer the calciferous types of spring (e.g. most of the gastropods species of Bythiospeum; Glöer 2002), which explains their absence in siliceous springs; this information might be missed by studying only microhabitat-fauna relationships and classifying by substrate type alone. This example illustrates abiotic filters at a hierarchical spatial scale: "a series of hierarchically nested environmental factors also influences the assemblage of species at progressively more localised spatial scales" (Allan and Castillo 2007:7). 
Table 1: Spatial-Functional Research Concept (Investigation Program).

\begin{tabular}{|c|c|c|c|}
\hline Area & & Functional Parameter & Individual Parameter \\
\hline \multirow{5}{*}{$\begin{array}{c}\text { Spring } \\
\text { (Eucrenal) }\end{array}$} & \multirow{3}{*}{ abiotic } & On-Site Measurements & $\begin{array}{l}\text { - Organoleptic Test } \\
\text { - In-situ-Measurements: Water Temperature, } \\
\text { pH, Electrical Conductivity, Oxygen Content } \\
\text { and Saturation }\end{array}$ \\
\hline & & $\begin{array}{c}\text { Hydrological / Hydro Morphological } \\
\text { Setting }\end{array}$ & $\begin{array}{l}\text { - Discharge (Estimation/Measurement) } \\
\text { - Type of Spring (Springhead Typology) } \\
\text { - Special Type (Habitat Typology) } \\
\text { - Arrangement of Springhead(s) (Individual, } \\
\text { Group) }\end{array}$ \\
\hline & & Structural State (Endangerment, Use) & $\begin{array}{l}\text { - Valley Head (Form of the Spring } \\
\text { Depression) } \\
\text { - Hydro Morphological Structures } \\
\text { - Types of Faunistic Ecotone } \\
\text { - Types of Substratum (Mineral, Organic) }\end{array}$ \\
\hline & \multirow{2}{*}{ biotic } & Fauna & $\begin{array}{l}\text { - Presence and Abundance (Sampling of } \\
\text { Invertebrates) } \\
\text { - Field Mapping (Non-Sampling, e.g. } \\
\text { Amphibians) }\end{array}$ \\
\hline & & Vegetation, Plants & - Higher Plants of the Spring Vegetation \\
\hline \multirow{3}{*}{$\begin{array}{l}\text { Spring Area } \\
\text { (Surrounding) }\end{array}$} & \multirow[t]{2}{*}{ abiotic } & Terrain Analysis (Geomorphology) & $\begin{array}{l}\text { - Hillside Situation (Position on a Slope) } \\
\text { - Inclination (Slope Steepness) } \\
\text { - Exposition } \\
\text { - Direction of the Discharge (Springbrook) }\end{array}$ \\
\hline & & Land use and forest structures & $\begin{array}{l}\text { - Crown Density (Canopy Layer, Trees) } \\
\text { - Type of Wood or Forest } \\
\text { - Biotope and Land Use Types } \\
\text { - Cleaved Forest (Share of Forest Clearence) }\end{array}$ \\
\hline & biotic & Plants & - Dominating Trees (Species) \\
\hline Spring Catchment & & Maps and Information systems & $\begin{array}{l}\text { Bedrock, Soil Type, Vegetation, } \\
\text { Geographical Classification of Natural } \\
\text { Landscapes }\end{array}$ \\
\hline
\end{tabular}


On the other hand, a precise analysis of the colonisation of substrate types on the subtopic level may explain the vegetation cover or land use (e.g., forest, extensive grass land, agriculture land) within the spring area. It is possible to differentiate fauna assemblages related to forest or non-forest structures by upscaling the aggregations of invertebrate species clusters.

When there is no woody debris nearby, for example, in non-forest spring areas, no woodsubstrate-specific taxa, such as xylophagous insects, will be found in the pools. With respect to scale, each dimension can be separated into intensity levels by process (Bastian 1991) with specific methods (Fig. 3). The investigation program illustrated in Table 1 defines key parameters not only for the isolated and detailed research topic of microhabitatfauna-relationships in the eucrenal of a spring but also for a multi-scale analysis of factors that influence the presence of invertebrates in spring ecotones. This spatial-functional research concept is divided into abiotic and biotic functional parameters, with a more detailed list of requirements to analyse the eucrenal, as for the spring area. This approach seeks to demonstrate that microhabitat-fauna relationships are not monocausal, as it might seem, but rather exhibit much interdependence. Moreover, parameters at many scales, from the habitat scale to the landscape scale, should be considered; a more complex investigation program is useful to detect possible influences on the presence of species. It must be emphasised that the parameters in the proposed spatial-functional research concept (Table 1) are not exhaustive or static; they can be added or replaced as required by the questions or objectives of the research. Furthermore, unique regional characteristics can be considered and incorporated accordingly.

\section{SUBTOPIC DIFFERENTIATION OF MICROHABITAT TYPES FOR SPRINGS}

The most dominant aggregated category of microhabitat types is the organic category, which contains $74.7 \%$ of all samples. This is a result of the focus on studying forest spring ecosystems because substrates such as macrophytes (spring vegetation) or leaf litter (CPOM) dominate coverage in the upper layer of these ecosystems. Pure mineral microhabitats without organic substrate types are rare, making up just $10.5 \%$ of all samples. The mixed habitat ( $7.2 \%$ of all samples) is a category where dominance of organic or mineral substrates is not possible. Artificial habitats make up $7.2 \%$ of all samples. The five most dominant microhabitat types (totalling 56.6\% of all samples) are CPOM-dominated, Psammopelal-abounded (19.7\%); Macrophytes-dominated, Psammopelal-abounded (13.2\%); CPOM-dominated, Microlithal-abounded (9.9\%); Macrophytes-dominated, Microlithal-abounded (7.9\%); and Psammopelal-dominated (5.9\%). These habitat types are ecological, as validated by taxa with a significant substrate preference ratio (Reiss 2012; Reiss 2011). The list of habitat types (Table 2) gives possible microhabitats for the springs studied here. 
Table 2: Habitat types of studied springs. Used terms see STAR/AQEM Classification (Hering et al. 2004). ${ }^{1}$ see description at the end of chapter 4 (ecohydrological habitat types)

\begin{tabular}{|c|c|c|c|}
\hline \multicolumn{2}{|c|}{ Habitat Type (HT) [Aggregation $\mathrm{HT}^{1}$ ] } & $\begin{array}{c}\text { No. } \\
\text { absolute }\end{array}$ & $\begin{array}{c}\text { No. } \\
\text { relative }\end{array}$ \\
\hline \multirow{20}{*}{$\begin{array}{l}\text { Organic } \\
74.7 \%\end{array}$} & CPOM dominated HT & 6 & $3.9 \%$ \\
\hline & CPOM dominated, Argyllal abounded HT [ $\left.\mathrm{O}_{\mathrm{f}}\right]$ & 3 & $1.9 \%$ \\
\hline & CPOM dominated, Psammal abounded $\mathrm{HT}\left[\mathrm{O}_{\mathrm{f}}\right]$ & 1 & $0.7 \%$ \\
\hline & CPOM dominated, Psammopelal abounded HT [O $\left.\mathrm{O}_{\mathrm{f}}\right]$ & 30 & $19.7 \%$ \\
\hline & CPOM dominated, Akal abounded $\mathrm{HT}\left[\mathrm{O}_{\mathrm{c}}\right]$ & 1 & $0.7 \%$ \\
\hline & CPOM dominated, Microlithal abounded $\mathrm{HT}\left[\mathrm{O}_{\mathrm{c}}\right]$ & 15 & $9.9 \%$ \\
\hline & CPOM dominated, Mesolithal abounded $\mathrm{HT}\left[\mathrm{O}_{c}\right]$ & 1 & $0.7 \%$ \\
\hline & CPOM dominated, Macrolithal abounded $\mathrm{HT}\left[\mathrm{O}_{\mathrm{c}}\right]$ & 1 & $0.7 \%$ \\
\hline & Macrophytes dominated HT & 4 & $2.6 \%$ \\
\hline & Macrophytes dominated, Psammopelal abounded HT [O $\left.\mathrm{O}_{\mathrm{f}}\right]$ & 20 & $13.2 \%$ \\
\hline & Macrophytes dominated, Microlithal abounded $\mathrm{HT}\left[\mathrm{O}_{\mathrm{c}}\right]$ & 12 & $7.9 \%$ \\
\hline & Macrophytes dominated, Mesolithal abounded $\mathrm{HT}\left[\mathrm{O}_{c}\right]$ & 1 & $0.7 \%$ \\
\hline & Macrophytes dominated, Megalithal abounded $\mathrm{HT}\left[\mathrm{O}_{c}\right]$ & 2 & $1.3 \%$ \\
\hline & Mooses dominated HT & 1 & $0.7 \%$ \\
\hline & Mooses dominated, Psammopelal abounded HT [O $\mathrm{O}]$ & 6 & $3.9 \%$ \\
\hline & Mooses dominated, Megalithal abounded $\mathrm{HT}\left[\mathrm{O}_{c}\right]$ & 3 & $1.9 \%$ \\
\hline & $\begin{array}{l}\text { Coniferous litter dominated, Psammopelal abounded HT } \\
{\left[\mathrm{O}_{\mathrm{f}}\right]}\end{array}$ & 3 & $1.9 \%$ \\
\hline & Xylal dominated, Psammopelal abounded $\mathrm{HT}\left[\mathrm{O}_{\mathrm{f}}\right]$ & 1 & $0.7 \%$ \\
\hline & Xylal dominated, Akal abounded $\mathrm{HT}\left[\mathrm{O}_{\mathrm{c}}\right]$ & 1 & $0.7 \%$ \\
\hline & No categorisation possible & 1 & $0.7 \%$ \\
\hline \multirow{4}{*}{$\begin{array}{l}\text { Mineral } \\
10.5 \%\end{array}$} & Psammopelal dominated HT $\left[\mathrm{M}_{\mathrm{f}}\right]$ & $\overline{9}$ & $5.9 \%$ \\
\hline & Microlithal dominated $\left[\mathrm{M}_{\mathrm{c}}\right]$ & 4 & $2.6 \%$ \\
\hline & Mesolithal dominated $\left[\mathrm{M}_{\mathrm{c}}\right]$ & 1 & $0.7 \%$ \\
\hline & No categorisation possible & 2 & $1.3 \%$ \\
\hline \multirow{5}{*}{$\begin{array}{l}\text { Mixed } \\
7.2 \%\end{array}$} & Psammopelal dominated mixed type $\left[\mathrm{O} / \mathrm{M}_{\mathrm{f}}\right]$ & 5 & $3.2 \%$ \\
\hline & Akal dominated mixed type $\left[\mathrm{O} / \mathrm{M}_{\mathrm{c}}\right]$ & 1 & $0.7 \%$ \\
\hline & Microlithal dominated mixed type $\left[\mathrm{O} / \mathrm{M}_{\mathrm{c}}\right]$ & 3 & $1.9 \%$ \\
\hline & Mesolithal dominated mixed type $\left[\mathrm{O} / \mathrm{M}_{\mathrm{c}}\right]$ & 1 & $0.7 \%$ \\
\hline & Megalithal dominated mixed type $\left[\mathrm{O} / \mathrm{M}_{\mathrm{c}}\right]$ & 1 & $0.7 \%$ \\
\hline \multirow{2}{*}{$\begin{array}{l}\text { Artificial } \\
7.2 \%\end{array}$} & Technolithal (open construction) $\left[\mathrm{T}_{0}\right]$ & 5 & $3.3 \%$ \\
\hline & Technolithal (closed construction) $\left[T_{c}\right]$ & 6 & $3.9 \%$ \\
\hline Special & Special type (spring fen) & 1 & $0.7 \%$ \\
\hline \multicolumn{2}{|l|}{ Total } & 152 & $100 \%$ \\
\hline
\end{tabular}


The list represents an open catalogue because it depends on the regional typology of springs within a study area in which each microhabitat type occurs. A detailed scheme also permits the subsequent aggregation of types to recognise differences and to make the analysis systematic. The following aggregation (compare with Table 2) for a microhabitat typology of springs is proposed as a framework to categorise ecohydrological habitat types:

$\mathrm{O}_{\mathrm{f}}$
$\mathrm{O}_{\mathrm{c}}$
$\mathrm{O}_{\mathrm{f}-\mathrm{c}}$
$\mathrm{M}_{\mathrm{f}}$
$\mathrm{M}_{\mathrm{c}}$
$\mathrm{M}_{\mathrm{c}-\mathrm{g}}$
$\mathrm{O} / \mathrm{M}_{\mathrm{f}}$
$\mathrm{O} / \mathrm{M}_{\mathrm{c}}$
$\mathrm{O} / \mathrm{M}_{\mathrm{c}-\mathrm{g}}$
type
$\mathrm{T}_{\mathrm{o}}$
$\mathrm{T}_{\mathrm{c}}$

organic-dominated, fine-material-abounded habitat type

organic-dominated, coarse-material-abounded habitat type

organic-dominated, fine- to coarse-material-abounded habitat type

mineral-dominated, fine-material-abounded habitat type

mineral-dominated, coarse-material-abounded habitat type

mineral-dominated, fine- to coarse-material-abounded habitat type

mixed type (organic/mineral), fine-material-abounded habitat type

mixed type (organic/mineral), coarse-material-abounded habitat type

mixed type (organic/mineral), fine- to coarse-material-abounded habitat

Technolithal with open construction

Technolithal with closed construction

\section{CONCLUSION}

A hierarchical spatial framework to study ecological conditions, particularly with regard to microhabitat-fauna relationships, and to develop a surface water typology of patchy forest spring habitats in various regions of the German low mountain ranges is proposed as a useful theoretical and practical basis for integrating landscape ecological approaches within hydrological methodologies. Various terms, dimensions and scale level classifications for water-related system components in hydrology and landscape ecology are brought into a functional context, clarifying the relationship between the river network and hydrotopes within the catchment to identify the ecological functions of spring habitats. Spatially hierarchical reference systems support the identification of the relationship between structures (hydro-morphology) and functions in surface water types. The ecological function of a substrate as a microhabitat for particular invertebrate taxa and their importance for the spring as a macrohabitat should also be considered. At the microscale level, springheads are patchy, i.e., the structure of the substratum is mosaic-like and heterogeneous. The smallest scale at which an organism responds to patchy structure is at the substrate level (Kotliar and Wiens 1990). This is where a species occurs (habitat) and can be detected in a sample. Using a multi-habitat sampling method to record the coverage fraction of each substrate type and the presence of fauna, it is possible to quantify the substratum at the nanoscale level. The hierarchical model provides a framework for classifying patchy structure across a range of scales: at the nanoscale level, it is possible to identify substrate types as microhabitats, while at the microscale level, one can aggregate habitat types to differentiate the springhead within a surface water typology. Furthermore, this approach recognises the ecological relevance of habitat types by analysing the substrate preference of invertebrate taxa. In the future, additional regional studies of spring ecosystems that categorise and validate more habitat types are needed; furthermore, spring 
types should be aggregated at the landscape scale to develop spring catalogues. First ecological spring catalogues exists, e.g. for the German federal states of Bavaria (Bayern) (BlfU 2008) and Rhineland-Palatinate (Rheinland-Pfalz) (LWRP 2002). These approaches would be useful for headwater protection planning and nature conservation management.

\section{REFERENCES}

Ahl, V. \& Allen, T.F.H., (1996). Hierarchy Theory: A Vision, Vocabulary, and Epistemology. New York: Columbia University Press.

Allan, J.D., (2004). Landscapes and Riverscapes: The Influence of Land Use on Stream Ecosystems. Annual Review of Ecology, Evolution, and Systematics 35:pp. 257-84. DOI: 10.1 146/annurev.ecolsys.35.120202.30000

Allan, J.D. \& Castillo, M.M., (2007). Stream Ecology. Structure and Function of Running Waters. Dordrecht: Springer.

Aspinall, R. \& Pearson, D., (2000). Integrated geographical assessment of environmental condition in water catchments: Linking landscape ecology, environmental modelling and GIS. Journal of Environmental Management 59: pp. 299-319. DOI: 10.1006/jema. 2000.0372

Barsch, H., (2000). Anforderungsprofil. In: Barsch, H.; Billwitz, K. \& Bork, H.-R. (Eds.): Arbeitsmethoden in der Physiogeographie und Geoökologie (pp. 17-24). Gotha: KlettPerthes.

Bastian, O., (1999). Geographie und Landschaftsplanung - Gedanken von Ernst Neef im Spiegel der modernen Landschaftsplanung. In: Mannsfeld, K. \& Neumeister, H. (Eds.): Ernst Neefs Landschaftslehre heute (pp. 13-35). Gotha: Klett-Perthes.

Bastian, O.; Beierkuhnlein, C.; Klink, H.-J.; Löffler, J.; Steinhardt, U. Volk, M. \& Wilmking, (2002). Vertical landscape structure and functioning. In: Bastian, O. \& Steinhardt, U. (Eds.): Development and Perspectives of Landscape Ecology (pp. 49-58). Dordrecht: Springer.

Becker, A., (1992). Methodische Aspekte der Regionalisierung. In: Kleeberg, H.B. (Ed.): Regionalisierung in der Hydrologie (pp. 16-32) Weinheim: Wiley-VCH.

BLfU, (2008) = Bayerisches Landesamt für Umwelt (Eds.) (2008). Aktionsprogramm Quellen in Bayern. Teil 1: Bayerischer Quelltypenkatalog. Hof: Beck Druck.

Bracken, L.J. \& Croke, J., (2007). The concept of hydrological connectivity and its contribution to understanding runoff-dominated geomorphic systems. Hydrological Processes 21: pp. 1749-1763. DOI: 10.1002/hyp.6313.

Büttner, G., Fetz, R., Hotzy, R. \& Römheld, J., (2004). Aktionsprogramm Quellen in Bayern - 1.Teil Bayerischer Quelltypenatlas. Augsburg: Landesamt für Umwelt.

Cantonati, M.; Füreder, L., Gerecke, R., Jüttner, I. \& Cox, E.J., (2012). Crenic habitats, hotspots for freshwater biodiversity conservation: toward an understanding of their ecology. Freshwater Science 31(2): pp. 463-480. DOI: 10.1899/11-111.1

Cheshmedjiev, S., Soufi, R., Vidinova, Y., Tyufekchieva, V., Yaneva, I., Uzunov, Y. \& Varadinova, E., (2011). Multi-habitat sampling method for benthic macroinvertebrate communities in different river types in Bulgaria. Water Research and Management 1 (3): pp. 55-58. 
Crutzen, P.J., (2006). The „Anthropocene”. In: Ehlers, E. \& Krafft, T. (Eds.): Earth System Science in the Anthropocene (pp. 13-18). Berlin: Springer.

Dierschke, H., (1994). Pflanzensoziologie. Stuttgart: Ulmer.

Drdoš, J., (1983). Landscape Research and its Anthropocentric Orientation. In: GeoJournal 7.2 (pp.155-160). DOI: 10.1007/BF00185163.

Duttmann, R., Bierbaum, J., Mosimann, T. \& Voges, J., (2000). Dimensionsübergreifende Modellierung des Wasser- und Stofftransportes am Beispiel eines GIS-basierten „downscalings“. In: Glawion, R. \& Zepp, H. (Eds.): Probleme und Strategien ökologischer Landschaftsanalyse und -bewertung (pp. 39-68). Flensburg: Deutsche Akademie für Landeskunde.

Ehlers, E., (2008). Das Anthropozän. Die Erde im Zeitalter des Menschen. Darmstadt: Wissenschaftliche Buchgesellschaft.

Frisell, C.A., Liss, W.L., Warren, C.E. \& Hurley, M.D., (1986). A hierarchical framework for stream habitat classification: Viewing streams in a watershed context. In: Environmental Management 10: pp. 199-214. DOI: 10.1007/BF01867358

Gebhardt, H., Glaser, R., Radtke, U. \& Reuber, P., (2011). Räumliche Maßstäbe und Gliederungen - von global bis lokal. In: Gebhardt, H., Glaser, R., Radtke, U. \& Reuber, P. (Eds.): Geographie. Physische Geographie und Humangeographie (pp. 13-35). Heidelberg: Spektrum.

Gehlker, H., (1977). Eine Hilfstafel zur Schätzung von Deckungsgrad und Artmächtigkeit. Mitteilungen der Florist.-Soziol. Arbeitsgemeinschaft N.F. 19/20: pp. 427-429.

Gibert, J., (1990). Groundwater systems and their boundaries: Conceptual framework and prospects in groundwater ecology. Verhandlungen der Internationalen Vereinigung für Theoretische und Angewandte Limnologie 24: pp. 1605-1608.

Gibert, J., Dole-Oliver, M.-J., Marmonier, P. and Vervier, P., (1991). Surface WaterGroundwater Ecotones. In: Naiman, R.J. \& Décamps H. (Eds.): The Ecology and management of aquatic-terrestrical ecotones (pp. 199-225). Paris: United Nations Educational, Scientific and Cultural Organization.

Gibert, J., Dole-Oliver, M.-J., Marmonier, P. \& Vervier, P., (1991). Surface WaterGroundwater Ecotones. In: Naiman, R.J. \& Décamps H. (Eds.): The Ecology and management of aquatic-terrestrical ecotones (pp. 199-225). Paris: United Nations Educational, Scientific and Cultural Organization

Glöer, P., (2002). Die Süßwassergastropoden Nord- und Mitteleuropas. Bestimmungsschlüssel, Lebensweise, Verbreitung. Hackenheim: ConchBooks.

Gurtz, J., Baltensweiler, A. \& Lang, H., (1999). Spatially distributed hydrotope-based modelling of evapotranspiration and runoff in mountainous basins. Hydrological Processess 13: pp. 2751-2768. DOI: 0.1002/(SICI)1099-1085(19991215)13:17<2751 ::AID-HYP897>3.0.CO;2-O.

Hering, D., Verdonschot, P.F.M., Moog, O. \& Sandin, L., (Eds.) (2004). Integrated assessment of running waters in Europe. Dordrecht: Springer.

Jungwirth, M., Haidvogl, G., Moog, O., Muhar, S. \& Schmutz, S., (2003). Angewandte Fischökologie an Fließgewässern. Wien: Facultas.

Kotliar, N.B. \& Wiens, J.A., (1990). Multiple scales of patchiness and patch structure: a hierarchical framework for the study of heterogeneity. Oikos 59: pp. 253-260.

Leser, H., (1997). Landschaftsökologie. Stuttgart: Ulmer 
Lischewski, D. \& Laukötter, G., (1993). Quellenkartieranleitung. Anleitung zur Quellkartierung in Nordrhein-Westfalen. Recklinghausen: Landesanstalt für Ökologie, Landschaftsentwicklung und Forstplanung.

LWRP (2002) = Landesamt für Wasserwirtschaft Rheinland-Pfalz (Eds.) (2002). Quelltypenatlas. Mainz: PrePress + Druck.

Magagna, B., Kollarits, S., Köck, R. \& Hochbichler, E., (2006). Mehr Transparenz in der Entscheidungsfindung durch Ontologien - das Beispiel Quellenschutz. In: Symposium und Fachmesse für Angewandte Geoinformatik AGIT-Symposium 5.7.-7.7.2006, (pp. 381-390). Salzburg: Universität Salzburg.

Meier, C., Haase, P., Rolauffs, P., Schindehütte, K., Schöll, F., Sundermann, A. \& Hering, D., (2006). Methodisches Handbuch Fließgewässerbewertung. Handbuch zur Untersuchung und Bewertung von Fließgewässern auf der Basis des Makrozoobenthos vor dem Hintergrund der EG-Wasserrahmenrichtlinie. http://www.fliessgewaesserbewertung.de

Meynen, E. \& Schmithüsen, J., (Eds.) (1953-1962). Handbuch der naturräumlichen Gliederung Deutschlands. 2 Bd. Bad Godesberg: Bundesanstalt für Landeskunde.

Morrison, M.L., Marcot, B.G. \& Mannan, R.W., (2006). Wildlife-habitat relationships. Concepts and Applications. Washington: Island Press.

Naveh, Z., (2000). What is holistic landscape ecology? A conceptual introduction. Landscape and Urban Planning 50: pp. 7-26. DOI: 10.1016/S0169-2046(00)00077-3.

Neef, E., (1963). Topologische und chorologische Arbeitsweisen in der Landschaftsforschung. Petermanns Geographische Mitteilungen 107: pp. 249-259.

Neef, E., (1967). Die theoretischen Grundlagen der Landschaftslehre. Gotha: VEB Verlag Haack.

Neumeister, H., (1999). Heterogenität - Grundeigenschaften der räumlichen Differenzierung in der Landschaft. In: Mannsfeld, K. \& Neumeister, H. (Eds.): Ernst Neefs Landschaftslehre heute (pp. 89-106). Gotha: Klett-Perthes.

O’Neill, R.O., (1988): Hierarchy and Global Change. SCOPE 35, pp. 29-45. http://www. scopenvironment.org/downloadpubs/scope35/

O’Neill, R.V., Johnson, A.R. \& King, A.W., (1989). A hierarchical framework for the analysis of scale. Landscape Ecology 3 (3/4), pp. 193-205.

Paffen, K.H., (1948). Ökologische Landschaftsgliederung. Erdkunde II, H.1/3 (Sonderheft): pp. 167-174.

Papadimitriou, F., (2010). Conceptual Modelling of Landscape Complexity. Landscape Research 35 (5): pp. 563-570. DOI: 10.1080/01426397.2010.504913.

Reiss, M., (2011). Substratpräferenz und Mikrohabitat-Fauna-Beziehung im Eukrenal von Quellgewässern. Doctoral dissertation ( $\mathrm{PhD}$ Thesis). Marburg. http://archiv.ub.unimarburg.de/diss/z2011/0108/

Reiss, M., (2012). Ökotonbasierte Analyse von Fauna-Habitat-Beziehungen in Quellgewässern als Beitrag für den Gewässerschutz. Forum für Hydrologie und Wasserbewirtschaftung 31.12: pp. 347-348.

Reiss, M. \& Opp, C., (2004). Ein Erfassungs- und Bewertungsverfahren der Gewässerstrukturgüte von Quellen und Quellbächen. In: Opp, C. (Ed.): Wasserressourcen Nutzung und Schutz. (pp. 155-189). Marburg: Marburger Geographische Gesellschaft. 
Schmithüsen, J., (1948). Fliesengefüge der Landschaft und Ökotop. Vorschläge zur begrifflichen Ordnung und Nomenklatur. Berichte zur Deutschen Landeskunde 5: pp. 7483.

Schmithüsen, J., (1949). Grundsätze für die Untersuchung und Darstellung der naturähnlichen Einheiten. Berichte zur Deutschen Landeskunde VI: pp. 8-19.

Schröder, B., (2006). Pattern, process, and function in landscape ecology and catchment hydrology - how can quantitative landscape ecology support predictions in ungauged basins? Hydrology and Earth System Sciences 10: pp. 967-979. DOI: 10.5194/hess-10-9672006.

Simon, H.A., (1962). The architecture of complexity. Proceedings of the American Philosophical Society 106 (6): pp. 467-482.

Steinhardt, U., (1999). Die Theorie der geographischen Dimensionen in der Angewandten Landschaftsökologie. In: Schneider-Sliwa, R.; Schaub, D. \& Gerold, G. (Ed.): Angewandte Landschaftsökologie. Grundlagen und Methoden (pp. 47-64). Berlin: Elsevier.

Steinhardt, U. \& Volk, M., (2000). Von der Makropore zum Flusseinzugsgebiet hierarchische Ansätze zum Verständnis des landschaftlichen Wasser- und Stoffhaushaltes. Petermanns Geographische Mitteilungen 144: pp. 80-91.

Steinhardt, U. \& Volk, M., (2003). Meso-scale landscape analysis based on landscape balance investigations: problems and hierarchical approaches for their resolution. Ecological Modelling 168: pp. 251-265. DOI: 10.1016/S0304-3800(03)00140-6.

Steinhardt, U., Blumenstein, O. \& Barsch, H., (2005). Lehrbuch der Landschaftsökologie. Heidelberg: Elsevier.

Troll, C., (1950). Die geographische Landschaft und ihre Erforschung. Studium Generale 3: pp. 163-181.

Vinogradov. Y.B., Semenova, O. M. \& Vinogradova, T. A., (2011). An approach to the scaling problem in hydrological modelling: the deterministic modelling hydrological system. Hydrological Processes 25: pp. 1055-1073. DOI: 10.1002/hyp.7901.

Pickett, S.T.A. and White, P.S., (Eds.) (1985). The Ecology of Natural Disturbance and Patch Dynamics. San Diego: Elsevier.

Wohlrab, B., Meuser, A. \& Sokollek, V., (1999). Landschaftswasserhaushalt - ein zentrales Thema der Landschaftsökologie. In: Schneider-Sliwa, R.; Schaub, D. \& Gerold, G. (Eds.): Angewandte Landschaftsökologie. Grundlagen und Methoden (pp. 277-302). Berlin: Springer.

Wu, J., (1999). Hierarchy and scaling: Extrapolating information along a scaling ladder. Canadian Journal or Remote Sensing 25 (4): pp. 367-380. 